\title{
The Concentration of 2-Propenyl Glucosinolate in Biofumigant Crops Influences Their Anti-Fungal Activity (In-Vitro) against Soil-Borne Pathogens
}

\author{
Oscar Villalta, Denise Wite, David A. Riches, Jorge Guiano, Vijey Chandolu, \\ Cassie Scoble, Caroline Donald, Ian J. Porter, Scott W. Mattner \\ Department of Environment and Primary Industries, Knoxfield, Victoria, Australia \\ Email: ovillalta@yahoo.com
}

Received 10 March 2016; accepted 23 April 2016; published 30 April 2016

\begin{abstract}
This study investigated the biofumigation potential of nine Brassica species/cultivars by determining the levels of 2-propenyl glucosinolate in their roots and shoots, and their in-vitro suppression of four major soil-borne pathogens of vegetable crops. Hydrolysis of 2-propenyl GSL produces volatile isothiocyanate (ITC) compounds which are known to have anti-fungal activity. HPLC results showed that 2-propenyl GSL only occurred in root and shoot residue of flowering plants of four Brassica cultivars developed for green manuring (Caliente 199 ${ }^{\circledR}$, Mustclean ${ }^{\circledR}, \mathrm{Nemfix}^{\circledR}$ and BQ Mulch ${ }^{\circledR}$ ) and in the standard (mustard seed meal) treatment Fumafert ${ }^{\circledR}$. Levels of 2-propenyl GSL varied several fold within the four Brassica cultivars, with $\mathbf{7 7 - 8 8 \%}$ of the total concentrations recorded in the shoot tissues. In in vitro assays, the level of fungal suppression by volatiles emitted by hydrated shoot and root residues related to their content of 2-propenyl GSL, and the dose of residue applied to five soilborne test pathogens (S. minor, Rhizoctonia solani, Fusarium oxysporum, Pythium dissotocum and Rhizoctonia solani). The variation in 2-propenyl GLS levels found in the Brassica green manure crops tested provides scope for selecting cultivars with greater potential for biofumigation, and to control multiple soil-borne disease problems in vegetable farms.
\end{abstract}

\section{Keywords}

Brassica, Glucosinolate, Soilborne Disease, Biofumigation, Sclerotinia

\section{Introduction}

Many soil-borne diseases are persistent problems in Australian vegetable farms, resulting in productivity losses due to reduced marketable yield, reduced plant growth, and lower quality. Effective management of the causal pathogens, particularly species of Sclerotinia, Fusarium, Pythium, and Rhizoctonia, is difficult due to their persistence in soil and lack of effective chemical controls [1]. Brassica green manures, rotation crops or seed meal 
amendments have been reported to suppress pest and disease organisms when grown or incorporated into the soil [2]-[4]. The suppression has been attributed to the production of volatile sulfur compounds through a process known as biofumigation, and to changes in soil microbial community structure. Brassica species and other members of Brassicacea contain glucosinolates (GSLs) in their tissues which when hydrolysed in the presence of the myrosinase enzyme (present endogenously in Brassica tissues), produce a range of products including oxazolidinethiones, nitriles, thiocyanates and various forms of volatile isothiocyanates (ITCs). The hydrolysis products, in particular the ITCs, are known to have broad biocidal activity including fungicidal and insecticidal effects [5] [6]. Biofumigation is thus a term used to describe the suppression of pest and soil-borne pathogens by biocidal compounds, principally ITCs, released when GSLs in Brassica rotation or green manure crops are hydrolysed in soil [7] [8]. Many Brassicas have been developed specifically as green manure crops for biofumigation purposes to control soil-borne pathogens and parasitic nematodes. In Australia, few studies have compared the GSL profiles and production in tissues of biofumigant crops, and the role of volatile compounds released from their hydrolysed root and shoot tissues against fungal pathogens [3] [8]. In this study, we focused on measuring the levels of 2-propenyl glucosinolate (2-propenyl GSL), a precursor of ITC and other sulfur compounds, in several Brassica biofumigants, particularly those relevant to the Australian vegetable industry. Biofumigants with different levels of 2-propenyl GSL were selected for fungal suppression studies in-vitro. The aim was to determine if suppression of four important soil-borne pathogens (species of Sclerotinia, Fusarium, Rhizoctonia and Pythium) of vegetable crops by the Brassica biofumigants could be demonstrated in-vitro, and if the level of suppression was related to concentration of 2-propenyl GSL in root and shoot tissues.

\section{Materials and Methods}

\subsection{Plant Material}

Plant tissues used in experiments were obtained from in a diverse set of Cruciferous plants with different levels of GSLs. The species/cultivars used were three high-GSL mustards Brassica juncea (Caliente 199 ${ }^{\circledR}$, Mustclean ${ }^{\circledR}$, Nemfix $^{\circledR}$ ), a low-GSL mustard B. juncea (Arid ${ }^{\circledR}$ ), a high-GSL rape/turnip mixture B. napus/B. campestris $\left(\right.$ BQ-Mulch ${ }^{\circledR}$ ) and a low-GSL rape B. napus, (Maxima-Plus ${ }^{\circledR}$ ). Other biofumigants used included rocket, Eruca sativus (Nemat ${ }^{\circledR}$ ), white mustard, Sinapis alba (Idagold ${ }^{\circledR}$ ), and fodder radish Raphanus sativus (Addagio ${ }^{\circledR}$ ). Seed was supplied by J. Kirkegaard (CSIRO, Canberra), with the exception of Caliente 199, Mustclean and BQ Mulch, which were purchased from local suppliers. The standard biofumigant treatment was Fumafert ${ }^{\circledR}$, a mixture of 66.6\% mustard seed meal (B. juncea) and 33.3\% neem kernel (Azadirachia indica), while oats (Avena sativa, Wintaro $\left.{ }^{\circledR}\right)$ was the control. The first set of plants used were grown in large pots (50 L) in a glasshouse $\left(8^{\circ} \mathrm{C}-12^{\circ} \mathrm{C}\right.$ ) from March to May 2008 (four plants of each species/cultivar in each pot, and two pots per entry arranged on two benches). The second set of plants was grown in sand beds from June to November 2008 (individual plots $1 \mathrm{~m} \times 1 \mathrm{~m}$ with $0.2 \mathrm{~m}$ inter-row (30 plants $/ \mathrm{m}^{2}$ ), two plots per entry). The plants were top dressed twice with fertiliser (20 kg/ha N; 20 kg/ha P and 18 kg/ha S), hand-weeded, and irrigated regularly.

\subsection{Glucosinolate Analysis}

At full flowering, two uniform plants were dug from each pot and four from each plot, and the soil washed from the roots. Roots and shoots (leaves, stems and flowers) were separated and frozen at $-20^{\circ} \mathrm{C}$. The plant samples were then freeze-dried and ground to a fine powder using an electric grinder with $1 \mathrm{~mm}$ screen, and the composite samples stored in sealed glass bottles at $-20^{\circ} \mathrm{C}$. The 2-propenyl GSL and total GSLs were extracted from 0.7 $\mathrm{g}$ of freeze-dried root and shoot tissues, and then identified and quantified according to a HPLC method described previously, with some modifications, using 2-propenyl (Sigma, St. Louis, MO, USA) as the standard [9]. GSLs were measured in two sub-samples from each composite sample of root or shoot residue from each of the species/cultivars tested.

\subsection{Mycelium Suppression Experiment}

Three experiments investigated the effect of volatile products, emitted from hydrated freeze-dried root and shoot residue, on mycelial growth of four soil-borne pathogens. The experiments used a vapour-exposure split-plate bioassay, modified from a method described previously [3]. In the bioassays, a 5 mm mycelial plug of a 4-5 day-old culture of the test pathogens was placed on PDA medium in half of a split petri plate. Biofumigant ma- 
terial was wetted sterile distilled water $(1.0$ - $2.0 \mathrm{~mL})$ to form a paste and then added to the other side of the split petri plate. The plates were sealed with parafilm and incubated in the dark at $20^{\circ} \mathrm{C}$. The fungal pathogens tested were Pythium dissotocum (complex), Sclerotinia minor, Rhizoctonia solani AG2.1, and Fusarium oxysporum. The isolates of the pathogens tested were obtained by the authors from vegetable farms in Victoria, Australia then grown in potato dextrose agar (PDA) and maintained at $22^{\circ} \mathrm{C}-25^{\circ} \mathrm{C}$ until used. The first experiment determined the effect of volatiles emitted from two doses ( $0.25 \mathrm{~g}$ and $0.50 \mathrm{~g}$ per plate) of root and shoot residue (all treatments, see Table 1) on mycelial growth of S. minor over a period of 5 days. After this period, residue was carefully removed from split plates and mycelial growth (radial) measured at 7 and 14 days after the start of the experiment. Mycelial plugs that did not show any grow after 14 days incubation were transferred to fresh PDA plates to determine if the effect of treatments was inhibitory or biocidal. The second experiment determined the effect of a shorter exposure time (48 hours) to volatiles emitted from 0.50 and $0.75 \mathrm{~g}$ of root and shoot residues from four (shoot) and two (root) Brassica treatments with different levels of 2-propenyl GSL (see Table 2).

Table 1. Mycelial growth (diameter) of $S$. minor after 5 days exposure to volatiles released from wetted shoot and root residues of biofumigant crops and a standard soil biofumigant in in vitro bioassays.

\begin{tabular}{|c|c|c|c|c|}
\hline \multirow{3}{*}{ Cultivar } & \multicolumn{4}{|c|}{ Radial mycelial growth (diameter, mm) 7 days } \\
\hline & \multicolumn{2}{|c|}{ Root residue (g) } & \multicolumn{2}{|c|}{ Shoot residue (g) } \\
\hline & 0.25 & 0.50 & 0.25 & 0.50 \\
\hline Untreated (Oats) & $28.00 \mathrm{a}$ & $28.00 \mathrm{a}$ & $28.00 \mathrm{a}$ & $28.00 \mathrm{a}$ \\
\hline Standard (Fumafert) & $0.00 \mathrm{~d}$ & $0.00 \mathrm{~d}$ & $0.00 \mathrm{c}$ & $0.00 \mathrm{c}$ \\
\hline Caliente 199 & $27.00 \mathrm{a}$ & 25.62 a & $0.00 \mathrm{c}$ & $0.00 \mathrm{c}$ \\
\hline Mustclean & $26.50 \mathrm{a}$ & $27.12 \mathrm{a}$ & $13.50 \mathrm{~b}$ & $0.00 \mathrm{c}$ \\
\hline Nemfix & $19.12 \mathrm{~b}$ & $0.00 \mathrm{~d}$ & $0.00 \mathrm{c}$ & $0.00 \mathrm{c}$ \\
\hline BQ-Mulch & 26.88 a & 26.49 a & 26.38 a & $6.38 \mathrm{bc}$ \\
\hline Arid & $27.12 \mathrm{a}$ & 26.75 a & 26.75 a & $25.12 \mathrm{a}$ \\
\hline Idagold & $26.88 \mathrm{a}$ & $27.12 \mathrm{a}$ & 26.38 a & $27.38 a$ \\
\hline Maxima & $26.75 \mathrm{a}$ & $26.62 \mathrm{a}$ & $26.12 \mathrm{a}$ & $24.62 \mathrm{a}$ \\
\hline Nemat & $27.62 \mathrm{a}$ & $26.88 \mathrm{a}$ & 26.88 a & $27.12 \mathrm{a}$ \\
\hline Addagio & $26.38 \mathrm{a}$ & $26.25 \mathrm{a}$ & $27.00 \mathrm{a}$ & $26.00 \mathrm{a}$ \\
\hline
\end{tabular}

Means within the same tissue with the same letters are not significantly different from each other at $p<0.05$. LSD $0.5=$ root $(5.3)$; shoot $=8.0$.

Table 2. Mycelial growth (diameter) of $S$. minor after 48 hours exposure to volatiles released from wetted shoot and root residues of biofumigant crops and a standard soil biofumigant in in vitro bioassays.

\begin{tabular}{ccccc}
\hline & \multicolumn{4}{c}{ Radial mycelial growth (diameter, mm) 7 days } \\
\cline { 2 - 5 } Cultivar & \multicolumn{2}{c}{ Root residue (g) } & \multicolumn{2}{c}{ Shoot residue (g) } \\
\cline { 2 - 5 } & $84.00 \mathrm{a}$ & $84.00 \mathrm{a}$ & $\mathbf{0 . 5 0}$ & $\mathbf{0 . 7 5}$ \\
\hline Untreated (Oats) & $0.00 \mathrm{c}$ & $0.00 \mathrm{c}$ & $84.00 \mathrm{a}$ & $0.00 \mathrm{c}$ \\
Standard (Fumafert) & $0.00 \mathrm{c}$ & $0.00 \mathrm{c}$ & $0.00 \mathrm{c}$ \\
Nemfix & $53.80 \mathrm{~b}$ & $0.00 \mathrm{c}$ & $0.00 \mathrm{c}$ & $0.00 \mathrm{c}$ \\
Caliente 199 & - & $0.00 \mathrm{c}$ & $0.00 \mathrm{c}$ & $40.75 \mathrm{~b}$ \\
BQ-Mulch & - & - & $75.75 \mathrm{a}$ & $84.00 \mathrm{a}$ \\
Mustclean & - & $51.50 \mathrm{~b}$ \\
\hline
\end{tabular}

Means within the same tissue with the same letters are not significantly different from each other at $p<0.05 . \mathrm{LSD}_{0.5}=\operatorname{root}(17.9)$; shoot $=(8.3)$. 
Mycelial plugs were removed from split plates after the 48 hours period, and then transferred to fresh PDA plates, and mycelial growth (diameter) measured as described above. The third experiment determined the effect of shorter exposure time (48 hours) to volatiles emitted from 0.25 and $0.50 \mathrm{~g}$ of shoot residues with low (BQ Mulch) and high (Caliente 199) levels of 2-propenyl GSL on mycelial growth of the four pathogens using the procedure described for the second experiment. There were four replicate plates of each treatment in each experiment, and the three experiments were repeated.

\subsection{Sclerotia Suppression Experiment}

A fourth experiment investigated the effect of volatiles released from $0.50 \mathrm{~g}$ of shoot residue of four Brassica treatments, with different levels of 2-propenyl GSL, on the viability of soil inoculum of $S$. minor (melanised sclerotia), using vapour and contact-exposure bioassays. Oat shoot residue was used as a control. The sclerotia used were produced in $S$. minor cultures grown for 5 weeks at $20^{\circ} \mathrm{C}$. The sclerotia were recovered from plates in a laminar flow cabinet and kept in sealed containers at room temperature until used. In the vapour-exposure method, a nylon netting bag containing seven sclerotia was placed into one side of a split plate, and $0.5 \mathrm{~g}$ of wetted shoot residue on the other side of the plate. In the contact-exposure method, sclerotia in the nylon bag were place directly on top of the residue in the middle of a petri plate. The plates were immediately sealed with parafilm and incubated for 48 hours in the dark at $20^{\circ} \mathrm{C}$. The sclerotia were then recovered and surface sterilised in a solution containing $80 \%$ ethanol and $5 \% \mathrm{NaOCl}(50: 50)$ for $3 \mathrm{~min}$, followed by three rinses in sterile distilled water, then placed individually on $20 \mathrm{~mm}$ diameter PDA droplets (5 per plate). The germination of sclerotia was recorded 7 and 14 days after initial incubation using a stereoscopic microscope, with sclerotia showing mycelial growth considered viable. There were four replicate mesh bags of each treatment, and the experiment was repeated.

\subsection{Data Analysis}

Individual bioassays were conducted as randomised complete block designs. Since the results of repeated experiments were similar based on F-tests, the data from repeated experiments were combined and then analysed by ANOVA to determine the effect of treatments, and interactions, on mycelial growth and sclerotia germination using GenStat v. 14.1 (Lawes Agricultural Trust, IACR Rothamsted 2013). Homogeneity of variance was determined by examining plots of fitted values versus residuals, while histograms of residuals examined for normality of distribution. When treatment effects were significant, means were compared using Fisher's least significant differences (LSD) tests, with statistical differences between means determined at the $5 \%$ significance level (where $p \leq 0.05$ ).

\section{Results}

\subsection{Glucosinolate Analysis}

The compound 2-propenyl GSL only occurred in shoot and root tissue of flowering plants of four Brassica green manure crops, and the soil treatment Fumafert (Figure 1). The concentration of 2-propenyl GSL differed markedly among the four cultivars, and between the root and shoot tissues. The concentration of 2-propenyl GSL was generally higher in shoot tissues $(77 \%$ - $88 \%$ of total concentrations measured in the plant) than in root tissues. Plants of Nemfix and Caliente 199 produced the highest total amount of 2-propenyl GSL (61 - 72 umol g-1 DW), while the concentration in Fumafert was about twice of that recorded in Nemfix $\left(149 \mu \mathrm{mol} \cdot \mathrm{g}^{-1}\right)$. Mustclean and BQ Mulch plants produced about 44\% and 29\% (18 - 27 mol g-1 DW) of the total 2-propenyl GSL recorded in Caliente 199 plants. All plants contained other unidentified GSLs. In shoot tissue, the total concentration of other GSLs was very low $(<5 \mu \mathrm{mol}$ g- $1 \mathrm{DW})$ in the low-GSL cultivars Maxima-Plus (fodder rape) and Arid (oil seed mustard), and much higher (18 to $35 \mu \mathrm{mol}$ g-1 DW) in the other eight cultivars tested (data not shown). In root tissue, total concentration of other GSLs ranged from 20 to $45 \mu \mathrm{mol}$ g-1 DW in plants of Addagio, Maxima-Plus, Nemat and Nemfix, and from 8 to $15 \mu \mathrm{mol} \cdot \mathrm{g}^{-1}$ in the other cultivars.

\subsection{Mycelium Suppression Experiment}

In the first experiment with S. minor, only volatile compounds released from hydrated Fumafert and freeze-dried 


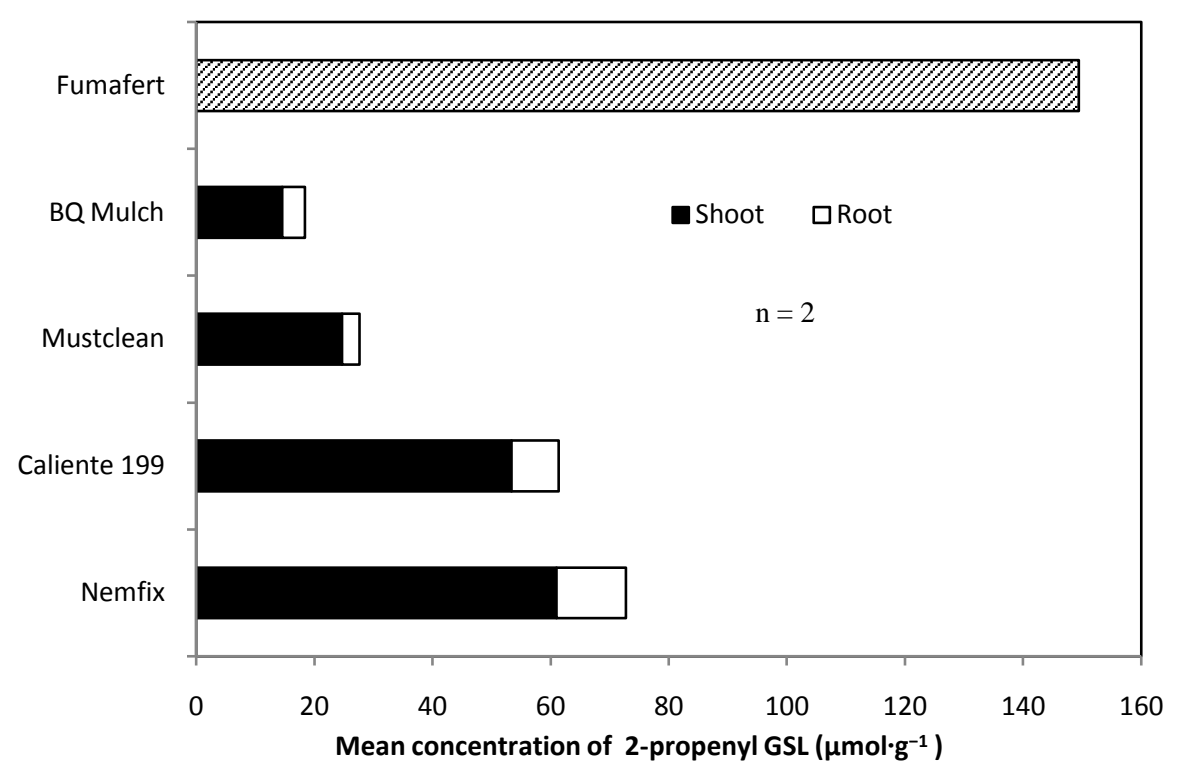

Figure 1. Concentration of 2-propenyl GSL in freeze-dried shoot and root residue of four Brassica green manure crops and the soil treatment Fumafert (standard biofumigant).

residue of plants containing 2-propenyl GSL significantly $(p<0.001)$ suppressed mycelial growth, compared to the untreated control (Table 1). Volatile compounds released from the other treatments were ineffective in suppressing mycelial growth, compared to the untreated control. Incubation of mycelial plugs that did not grow (i.e. complete suppression) after transfer to fresh PDA plates indicated that the suppression effect was biocidal (i.e. fungi were killed), and not fungistatic. In both $S$. minor experiments, significant interactions ( $<<0.001)$ between treatments and the doses of residue tested suggested that the level of suppression was related to levels of 2-propenyl GSL in residue tested. Volatiles released from Fumafert and shoot residue of Nemfix and Caliente 199 completely suppressed mycelial growth of $S$. minor after long exposure (5 days) to low ( $0.25 \mathrm{~g}$ ) and moderate $(0.50 \mathrm{~g})$ doses, and short exposure (48 hours) to moderate and high ( $0.75 \mathrm{~g})$ doses (Table 1 and Table 2). Long exposure to low and moderate doses of shoot residue of Mustclean suppressed mycelial growth more than short exposure to high doses. Similar results were obtained with shoot residue of BQ Mulch. Of the root residues tested, only volatiles released from Nemfix and Caliente 199 resulted in significant suppression of S. minor mycelial growth, particularly at higher doses (Table 1 and Table 2). In the third experiment with the four pathogens, volatiles released from Fumafert and shoot residue with high levels of 2-propenyl GSL (Caliente 199) were significantly more effective in suppressing mycelial growth than volatiles from residue (BQ Mulch) with low levels of the compound (Table 3). Short exposure to volatiles released from low and moderate doses of Fumafert and residue of Caliente 199 completely suppressed mycelial growth of S. minor, P. dissotocum and F. oxysporum, compared to the untreated control. Volatiles released from moderate doses of Caliente 199 residue completely suppressed mycelial growth of $R$. solani, while the small dose only delayed growth. Volatiles released from small and moderate doses of BQ Mulch residue completely suppressed mycelial growth of $P$. dissotocum, but were ineffective against $F$. oxysporum. Moderate doses of BQ Mulch residue delayed mycelial growth of $S$. minor and $R$. solani, but not small doses. In all three experiments, significant differences (in delayed mycelial growth) between treatments only occurred after 7 days of incubation and not after 14 days (data not shown).

\subsection{Sclerotial Suppression Experiment}

Volatiles released from residues (0.50 g) containing high levels of 2-propenyl GSL (Fumafert, Caliente 199 and Nemfix) significantly $(p<0.001)$ reduced the viability of sclerotia, compared to the untreated control (Figure 2). A significant interaction $(p<0.001)$ occurred between treatment and fumigation method (vapour or contact). Volatile compounds released from Fumafert significantly reduced the number of viable sclerotia from five to about one, irrespective of fumigation method. In contrast, volatiles released from shoot residue of Caliente 199 


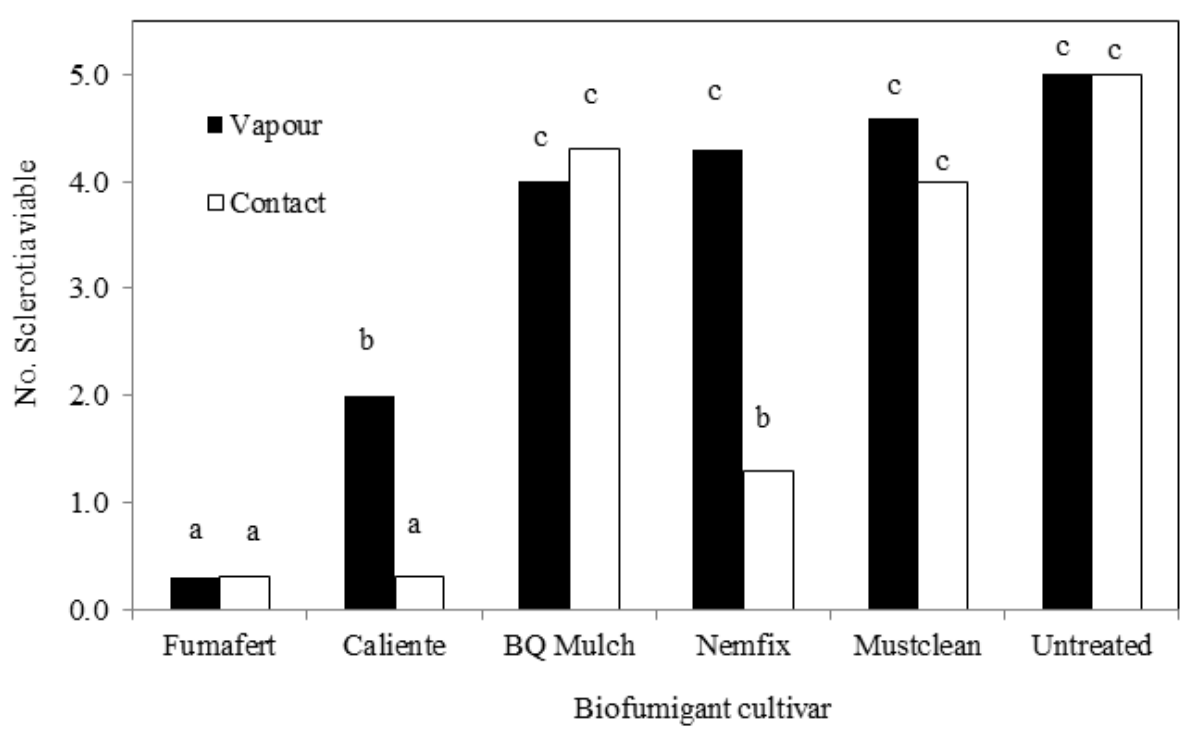

Figure 2. Number of sclerotia of $S$. minor viable after 48 hours exposure to volatiles from wetted shoot residues of biofumigant crops and a standard biofumigant in vapour and contact in vitro bioassays. Means with the same letters are not significantly different from each other at $p<0.05$. LSD0.5 $=1.2$.

Table 3. Mycelial growth (diameter) of five soil-borne fungal pathogens after 48 hours exposure to volatiles from wetted shoot residues of biofumigant crops and a standard soil biofumigant in in vitro bioassays.

\begin{tabular}{cccccc}
\hline \multirow{2}{*}{ Cultivar } & \multicolumn{5}{c}{ Pathogen- mycelial growth (diameter, mm) 7 days } \\
\cline { 2 - 6 } & Residue (g) & S. minor & P. dissotocum & F. oxysporum & \multicolumn{2}{c}{ R. solani } \\
\hline Untreated (oats) & 0.25 & $80.0 \mathrm{a}$ & $58.7 \mathrm{a}$ & $58.7 \mathrm{a}$ & $80.0 \mathrm{a}$ \\
& 0.50 & $80.0 \mathrm{a}$ & $58.0 \mathrm{a}$ & $59.8 \mathrm{a}$ & $80.0 \mathrm{a}$ \\
\multirow{2}{*}{ Fumafert } & 0.25 & $0.00 \mathrm{c}$ & $0.00 \mathrm{~b}$ & $0.00 \mathrm{~b}$ & $0.00 \mathrm{c}$ \\
& 0.50 & $0.00 \mathrm{c}$ & $0.00 \mathrm{~b}$ & $0.00 \mathrm{~b}$ & $66.7 \mathrm{ab}$ \\
Caliente 199 & 0.25 & $0.00 \mathrm{c}$ & $0.00 \mathrm{~b}$ & $0.00 \mathrm{~b}$ & $0.00 \mathrm{c}$ \\
& 0.50 & $0.00 \mathrm{c}$ & $0.00 \mathrm{~b}$ & $50.0 \mathrm{~b}$ \\
\hline
\end{tabular}

Means within the same pathogen with the same letters are not significantly different from each other at $p<0.05$. $\mathrm{LSD}_{0.5}=$ S. minor (17.9); P. dissotocum (5.2); F. oxysporum (17.8); R. solani (28.0).

caused significantly greater reduction of sclerotia viability in the contact than the vapour fumigation method. The volatiles released from shoot residue of Nemfix significantly reduced sclerotia viability only in the contact method. Volatile compounds released from the other two treatments were ineffective in reducing sclerotial viability, compared to the untreated control.

\section{Discussion}

The results from this study demonstrate the in-vitro potential of Brassica tissues to suppress or kill four soil-borne fungal pathogens of vegetables, and provide evidence that suppression is related to the level of 2-propenyl GSL in the plant tissues. Mustards (B. juncea) contain relatively high levels of 2-propenyl GSL, which is known to produce highly toxic ITCs, upon hydrolysis, against fungal pathogens [5] [8]. The levels of 2-propenyl GSL were several folds higher in the shoot (leaves and stems) than roots of the four biofumigant Brassica green manure crops tested. This was expected because they have been commercially selected to pro- 
duce vigorous leaf production for green manuring (where roots and shoots are incorporated) to enhance biofumigation in various agricultural and horticultural applications [8]. S. minor was selected as the main test fungus as it is one of the most difficult soil-borne pathogens to control in lettuce, beans and other vegetable crops due to its persistence in soil [1]. The level of mycelial growth and inoculum (sclerotia) suppression by the biofumigant treatments observed in-vitro was related to the levels of the 2-propenyl GSL recorded in plant tissue. The seed meal treatment Fumafert had the highest content of 2-propenyl GSL, and as a result it was highly effective in killing mycelium and inoculum (sclerotia) of $S$. minor. The availability and cost of this product may make it most suitable for use as a soil amendment and biofumigant for management of S. minor and other soil-borne pathogens in high-cash and protected crops, or when crop rotations are not possible. Flowering plants of the $B$. juncea cultivars Caliente 199 and Nemfix also contained high levels of 2-propenyl GSL. The volatiles emitted from wetted shoot residues of these cultivars were also biocidal to mycelium and inoculum (sclerotia) of S. minor. This concurs with previous work that showed that air-dried and crushed mustard (B. juncea) residue added to soil effectively reduced the viability of sclerotia of the onion pathogen Sclerotium cepivorum [10]. The volatiles of Caliente 199 and Fumafert were also biocidal to mycelium of the other three soil-borne pathogens ( $P$. dissotocum, F. oxysporum and $R$. solani) tested. In contrast, volatiles released from residues of the cultivars BQ Mulch and Mustclean were generally less effective in suppressing mycelial growth of S. minor and the other three pathogens, most likely due to their lower content of 2-propenyl GSL in their tissues. The availability of biofumigant crops with high content of 2-propenyl GLS, such as Caliente 199 and Nemfix, may provide an opportunity to manage soil-borne pathogens in the field following their incorporation into moist soil. Results from our bioassays also showed that wetted residues of Caliente 166 and Nemfix killed sclerotia of S. minor more effectively on contact with the pathogen, than when the pathogen was only exposed to volatiles from the residues. This may suggest that other non-volatile allelochemicals from biofumigant crops also contribute to pathogen suppression (e.g. nitriles [3], but further research would be needed to determine and characterise these compounds. Further work is also required to determine the agronomic requirements and biofumigation potential of the Brassica crops tested in this study for reducing soil-borne pests and pathogens in vegetable cropping systems. This can be achieved by evaluating Brassica green manure crops with different levels of 2-propenyl GLS in rotation with vegetables during cool weather to precede spring and summer vegetables. Plants from the cultivars tested in this study have a range of other GSLs that have been shown to offer other potential benefits for vegetable crops. For instance, the fodder radish Addagio ( $R$. sativus) is a useful nematode resistant cover-crop. Field trials should therefore also evaluate other soil benefits associated with the use of biofumigant crops in vegetable rotations, including increases in organic matter and beneficial soil micro-organisms.

\section{Conclusion}

Results from this study showed that four of the biofumigant Brassica crops tested (Caliente 199, Mustclean, and BQ Mulch) contain the aliphatic 2-propenyl GSL (trivial name Sinigrin). This compound is a precursor of allyl-ITC, which has been shown to be highly toxic against fungal pathogens. Biofumigant crops with high levels 2-propenyl GSL showed greater fungal suppression of four soil-borne pathogens of vegetables in-vitro. The variation in 2-propenyl GLS levels found in the four Brassica crops provides scope to select cultivars with greater potential for soil biofumigation to manage different soil-borne pathogens in vegetable cropping systems. Further studies are needed to assess the efficacy of residues with different levels of 2-propenyl GSL on pest and pathogen suppression under commercial conditions to determine the magnitude of the benefits of biofumigation.

\section{Acknowledgements}

The authors wish to thank Michael Imsic for helping with GSL measurement and John Kirkegaard for supplying seed for some of the Brassicas cultivars tested. The provision of funds to support this research by the Australian Vegetable Industry, through Horticulture Australia Limited, and the Victorian Government, through the Department of Primary Industries, Victoria, are gratefully acknowledged.

\section{References}

[1] Villalta, O.V., Wite, D., Hunt, J., Stewart, A. and Porter, I.J. (2012) Biological Control of Sclerotinia Minor on Lettuce Using Trichoderma and Coniothyrium Species. Acta Horticulturae, 944, 50-51.

http://dx.doi.org/10.17660/ActaHortic.2012.944.6 
[2] Larkin, R.P. and Griffin, T.S. (2007) Control of Soilborne Potato Disease Using Brassica Green Manures. Crop Protection, 26, 1067-1077. http://dx.doi.org/10.1016/j.cropro.2006.10.004

[3] Mattner, S.W., Porter, I.J., Gounder, R.K., Shanks, A.L., Wren, D.J. and Allen, D. (2008) Factors That Impact on the Ability of Fumigants to Suppress Fungal Pathogens and Weeds of Strawberry. Crop Protection, 27, 1165-1173. http://dx.doi.org/10.1016/j.cropro.2008.02.002

[4] Brown, P.D. and Morra, M.J. (1997) Control of Soil-Borne Plant Pests Using Glucosinolate-Containing Plants. Advances in Agronomy, 61, 167-231. http://dx.doi.org/10.1016/S0065-2113(08)60664-1

[5] Drobnica, L., Zemanova, M., Nemec, P., Antos, K., Kristian, P., Stullerova, A., Kuoppova, V. and Nemec Jr., P. (1967) Antifungal Activity of Isothiocyanates and Related Compounds. I. Naturally Occurring Isothiocyanates and Their Analogues. Applied Microbiology, 15, 701-709.

[6] Sarwar, M., Kirkegaard, J.A., Wong, P.T.W. and Desmarchelier, J.M. (1998) Biofumigation Potential of Brassicas III. In Vitro Toxicity of Isothiocyanates to Soil-Borne Fungal Pathogens. Plant \& Soil, 201, 103-112. http://dx.doi.org/10.1023/A:1004381129991

[7] Morra, M.J. and Kirkegaard, J.A. (2002) Isothiocyanate Release from Soil-Incorporated Brassica Tissues. Soil Biology \& Chemistry, 34, 1683-1690. http://dx.doi.org/10.1016/S0038-0717(02)00153-0

[8] Kirkegaard, J.A. and Sarwar, M. (1998) Biofumigation Potential of Brassicas. Plant and Soil, 201, 71-89. http://dx.doi.org/10.1023/A:1004364713152

[9] West, L., Tsui, I. and Haas, G. (2002) Single Column Approach for the Liquid Chromatographic Separation of Polar and Non-Polar Glucosinolates from Broccoli Sprouts and Seeds. Journal of Chromatography A, 966, 227-232. http://dx.doi.org/10.1016/S0021-9673(02)00734-3

[10] Smolinska, U. and Horbowicz, M. (1999) Fungicidal Activity of Volatiles from Selected Cruciferous Plants against Resting Propagules of Soil-Borne Fungal Pathogens. Journal of Phytopathology, 147, 119-124. http://dx.doi.org/10.1111/j.1439-0434.1999.tb03817.x 